\title{
Ownership Structure and Cash Flows As Determinants of Corporate Dividend Policy in Pakistan
}

\author{
Talat Afza (Corresponding Author) \\ Faculty of Business Administration, COMSATS Institute of Information Technology \\ Jinnah Building Defence Road, Off Raiwind Road, Lahore, Pakistan \\ E-mail: talatafza@ciitlahore.edu.pk \\ Hammad Hassan Mirza \\ COMSATS Institute of Information Technology, Park Road, Chak Shahzad, Islamabad, Pakistan \\ E-mail: al_hammd@hotmail.com
}

\begin{abstract}
s
Dividend Policy is among the widely addressed topics in modern financial literature. The inconclusiveness of the theories on importance of dividend in determining firm's value has made it one of the most debatable topics for the researchers (see for example, Ramcharan, 2001; Frankfurter et. al 2002; Al-Malkawi, 2007). The present study investigates the impact of firm specific characteristics on corporate dividend behavior in emerging economy of Pakistan. Three years data (2005-2007) of 100 companies listed at Karachi Stock Exchange (KSE) has been analyzed using Ordinary Least Square (OLS) regression. The results show that managerial and individual ownership, cash flow sensitivity, size and leverage are negatively whereas, operating cash-flow and profitability are positively related to cash dividend. Managerial ownership, individual ownership, operating cash flow and size are the most significant determinants of dividend behavior whereas, leverage and cash flow sensitivity do not contribute significantly in determining the level of corporate dividend payment in the firms studied in our sample. Estimated results are robust to alternative proxy of dividend behavior i.e. dividend intensity.
\end{abstract}

Keywords: Dividend Policy, Ownership Structure, Cash Flow, OLS Regression

\section{Introduction}

Dividend policy is among the widely addressed topics in modern financial literature. The inconclusiveness of the theories on perceived importance of dividend policy in determining firm's value has made it one of the most debatable topics for researchers. This debate is rooted back to the seminal work of Modigliani and Miller (1961), in which they challenged the common belief that payment of dividend increases firm's value and argued that in perfect capital market a firm's dividend decision does not affect its value. But on the other hand, Lintner (1962) and Gordon (1963) supported "Bird-in-the-hand" theory and argued that in the world of uncertainty and imperfect information, high dividend payment is associated with high firm value. The above debate has now turned into voluminous financial literature, but the issue seems to be stagnant at the same point where Black (1976) called it a "Puzzle" whose pieces do not fit together. There is emerging consensus that no single factor alone can explain dividend behavior (Anil and Sujjata, 2008). Financial researchers have identified a variety of firm specific factors, which are important in making dividend decision including the ownership structure.

The existing corporate theories support the relationship between ownership structure and dividend behavior due to "Agency problem" (Easterbrook, 1984; Jensen, 1986), which argue that dividend provides indirect benefit of control where active monitoring of a firm's management by its shareholders is missing (Rozef, 1982). Dividends can potentially mitigate this problem by curtailing the funds under manager's control and force management to the capital market more frequently for acquisition of funds, thus putting them under the strict scrutiny of funds suppliers in external capital market. Jensen and Meckling (1976) argued that agency cost might be reduced if insiders increase their ownership in the firm, because this will align the interest of both managers and shareholders by making the managers, ultimate owners of company but on the other hand, this ultimate ownership by management will give rise to new conflicts of interest between insiders and outsiders, as managers will try to accumulate more funds under their control either by reducing dividend payments or by maintaining payout at low level. Furthermore, "Clientele Effect Model", argues that investors are attracted towards the company whose payout policy best suits their investment objectives because investors face different tax treatments on dividend and capital gain and incur cost when they trade securities. Therefore, their preference towards dividend and capital gain create clienteles which force them to select a company whose dividend policy is aligned with their investment strategy. In the context of Pakistani taxation system, tax on dividend is deducted at source whereas, capital gain is totally exempted from tax. Therefore, it is not surprising to note that investors, 
especially individuals having small holdings prefer capital gain over dividends.

In addition to ownership structure, company's financial and liquidity position also plays an important role in determining the level of dividend. If a company is facing liquidity problem then it may prefer to choose stock dividend rather than cash dividends. According to Jensen's (1986) Free Cash Flow Hypothesis, companies prefer to use their cash resources to invest in profitable projects first and dividends are paid out of residual. Berle and Means (1932), who first time introduced the concept of separation of ownership and management (cited in Afza and Slahudin, 2009), argued that the inefficient use of cash resources, in excess of profitable investment opportunities by management, causes conflict of interest between ownership and management. Dividend and interest payment reduces the free cash flow available to management, hence reducing the chance of using it in less profitable projects or on managers' prerequisites. From companies' point of view, cash generated from operations plays an important role in deciding the amount of payout, companies having greater cash flow generated from operations are expected to be in a better position to pay cash dividends rather than companies having negative operating cash flows. From cash flow sensitivity point of view prior studies reported that financially constrained firms accumulate higher cash holdings and retain greater portion of the cash earned during the period, which means that liquidity is more important when firms cannot raise funds from external market and liquid resources are required for investment in future profitable projects (Khurana et. al., 2006). Almeida et. al. (2004) pointed out that firms facing financial constraints will save more cash today to fund future investment opportunities. Intuitively, increasing tendency of saving cash out of free cash flows will indicate the availability of profitable projects and financial constraints and hence will reduce the payout ratio of the firm, provided that firms' access to external finance is limited to a certain level.

The level of financial constraints a company is facing also depends on its size which is an important factor in determining the payouts of company since large size firms have easy access to external capital market due to the higher value of their assets and positive growth prospective and do not reduce their dividends in order to finance the future profitable projects unless it became absolutely unavoidable for them. This argument assumes the availability of established debt market from where these firms can acquire loan. Small firms on the contrary, having limited access to external market try to increase the level of internally generated funds by increasing their retention ratio which potentially reduces the small firm's capability of paying dividend as they are financially more constrained. Not only the size but also firm's capital structure affects its dividend decisions. Darling (1957) argued that firms with higher debt ratio require more liquidity to allow for payoffs on potential claims. Debts besides levering up company's profit also put the company in danger of insolvency due to non-payment of interest and have an adverse affect on firm's liquid position. Payment of interest potentially reduces the company's cash flows available for dividend payments because of which companies having high debt ratio pay low dividends (Rozef, 1982). On the other hand, profitability is also considered to be among the prime determinants of dividend payout. Lintner (1956) in his classical study found that a firm's net earnings are the critical determinant of dividend change and DeAngelo et. al (1992) argued that current income is a critical determinant of dividend decision that is why managers are reluctant to reduce dividend payments except during periods when earnings are very poor (Mayers and Frank, 2008). Fama and French (2002) also reported that more profitable firms pay higher dividends.

Since ownership structure is taken as one of the key variables influencing the corporate dividend behavior it seems necessary to highlight some characteristics of Pakistan's Corporate and Economic scenario. Pakistan's corporations are dominated by concentrated family ownership, which is opposite to the Anglo-American structure of dispersed ownership due to which in Pakistan majority shareholders not only retain control of the company but also are engaged in managing it (Ibrahim, 2005). Generally, companies are small in size primarily because of limited access to external capital market. Moreover, management is reluctant to use equity financing because this could potentially reduce management's ownership in the company. Shareholder's rights are not fully protected by Companies Ordinance 1984 which requires shareholders to have $20 \%$ or more shares in order to take necessary action through court against any negligence in company's affairs by management. Shareholders having less then $20 \%$ but greater then $10 \%$ shares can apply to Security and Exchange Commission of Pakistan (SECP) for appointment of inspector to investigate the company's affairs. Shareholders having less then $10 \%$ shares cannot apply to court or SECP (Ibrahim, 2005). Furthermore, corporate taxation policy adversely affects the preference of small investors towards dividends because dividends are taxed at source at the rate of $10 \%$ and companies are taxed at the rate of $35 \%$ on their earnings which makes dividend subject to double taxation. Whereas, capital gains are exempted from tax as result capital gains seem more attractive for investors rather than dividends.

Furthermore, Pakistan was among the best performing economies of the south Asian region till 2007. According to Economic Survey of Pakistan 2007-08, in last 6 years Pakistan's economy has shown a record growth in its 
Gross Domestic Product (GDP) and Equity Market Indices. In the year 2007 it's GDP grew at the rate of 6.9\% but declined again to $5.8 \%$ in 2008. KSE broke a series of records and became the sixth best performer among the emerging markets in the calendar year 2007 (Economic Survey of Pakistan 2007-08). KSE 100 index stood at $1,366.44$ in 2001 and reached to $14,075.83$ on December 2007. From this we can conclude that the period under study (2005 to 2007) was in general a period of high growth opportunities for the companies.

The empirical findings on the impact of firm specific characteristics on dividend behavior are inconclusive. Existing studies have focused on the dividend behaviors of companies in developed economies like USA and UK, but the evidence form emerging economies is very limited. In the context of Pakistan, recently Ayub (2005) and Ahmed and Attiya (2009) has studied determinants of dividend policy but both studies did not consider the cash flow aspect, which is argued by many researchers as a potential determinant of dividend policy (See for example, Lawson, 1996; DeAngelo and DeAngelo, 2006; ). Furthermore, the evidence on impact of ownership structures on payout of Pakistani companies is also very limited. Therefore, present study attempts to extend this literature by examining the impact of cash flows and ownership structure on corporate payouts.

The present study is different from the previous Pakistani studies based on the variables used as determinants of dividend payout. Impact of ownership structure i.e. managerial and individual ownership, on dividend payout behavior is to be analyzed further and cash flow sensitivity and operating cash flow as determinants of dividend payout behavior are yet to be studied in Pakistani context. Therefore, this study is an attempt to explore the impact of these corporate characteristics on dividend behavior of companies in emerging economy of Pakistan. It is expected that the results of this study will provide an insight into the trends and dynamics of dividend policy and its determinants.

Rest of the article is organized as follows. Section 2 provides the review of relevant literature. Research methodology is presented in Section 3. Section 4 reports the results and final section gives conclusion and some policy implications.

\section{Literature Review}

Existing literature is enriched with theoretical explanations and empirical evidence on the behavior of corporate dividend policy. Many researchers have analyzed the impact of ownership structure on dividend payouts but very few have considered proportion of shares held by managers and cash flow sensitivity as determinants of dividend payout policy. The literature on determinants of dividend policy has its roots in the legendary paper of Lintner (1956) in which he found the changes in earnings and existing divided rates are the most important determinants of a company's dividend decision. Afterwards, Miller and Modigliani (1961) presented the irrelevance proposition and proved that in a perfect capital market firm's dividend decision is not a thing of value at all. During the last fifty years, the enduring nature of debate on dividend policy has generated a rich body of literature in which the majority of the researchers support that the payment of dividends has a positive impact on firms' value but on the other hand many researchers have argued that payment of dividends affect the firm's value negatively, still many others believe that dividend decisions is not a thing of value and have no significant impact on firms' perceived financial position.

Jensen and Meckling (1976) focused on the issue of Agency Cost Hypothesis and reported that dividend curtails the funds under management control, thus putting them under strict capital market scrutiny. This reduces the owner's responsibility to manage the quality of investment and to control the expenditure on manager prerequisites. Baker and Wurgler (1963) presented the other side of the picture in their Catering Theory and argued that management should give incentives to shareholders according to their demands, this is the way to cater the investors by paying smooth dividends when investors put premium on dividend paying companies and by not paying dividends when they prefer non-paying companies. Easterbrook (1984) argued that payment of dividend keeps the company in capital market where monitoring is less costly and it also reduces the level of risk taken by managers and different classes of investors. Mayers (1984) presented Pecking Order Theory, according to which a company follows a sequence in utilization of funds for investments, primarily retained earnings are used which are less costly source of funds followed by debt and equity as the sources of funds. Fama and French (2002) tested Pecking Order and Trade-Off theories simultaneously and concluded that more profitable firms have higher dividend payouts, firms with more investment have lower payouts and the relationship between leverage and payout is negative. Gordon and Walter (1985) presented Bird In Hand Theory and argued that investors prefer cash in hand (dividend) than realizable future expected profits (Capital Gain). Bhattacharya (1980) supported Signaling Hypothesis, according to which dividend reduces the information asymmetry between managers and shareholders by providing information regarding the firm's future growth prospects.

In addition to the dividend payouts theories, existing literature also provides empirical evidence on determinants of dividend policy from almost every part of the world. Purnanadam and Rao (1965) used Lintner's Dividend 
Model to test long run desired dividend payout in Indian Cotton Textile Industry from a sample of 50 companies having paid up capital of more then Rs. 1 million over the period from 1946 to 1963 and found that the long term desired dividend payout ratio and reaction coefficient are inversely related. He argued that target payout is explainable in terms of variance of net income, the extent of managerial conservatism, and the amount of importance attached to dividend stability.

Bradley et. al. (1998) explored the role of expected cash flow volatility as a determinant of dividend policy both theoretically and empirically on the sample of 75 REIT firms form 1985 to 1992 and found that payout ratio is lower for firms with higher expected cash flow volatility, controlling for leverage, size and property level diversification. Their findings were in line with information based explanation of dividend policy but not with agency cost explanation.

A comparative study of dividend policy in Australia and Japan was conducted by Ho (2002) in which he examined the panel data of stocks from ASX 200 and Nikkei 225 index using fixed effect regression model and found that dividend policy is positively affected by size in Australia and by liquidity in Japan and negatively by risk, in Japan only. Industry effect is found to be significant in both the countries.

Gugler (2003) examined the relationship between dividend and ownership control structure for a panel of 214 non financial Australian firms from 1991 to 1999 using OLS technique and reported that state owned firms were engaged in dividend smoothing while family controlled firms were not. In addition, the state owned firms were most reluctant and family owned firms were least reluctant to cut dividends and also observed that firms with low growth opportunities optimally disgorge cash irrespective of who controls the firm.

Myers and Frank (2004) empirically examined the data for a sample of 483 firms from Multex Investor Database using OLS regression techniques to assess the impact of selected financial variables on the dividend decision and found that the higher Price to Earning is related with higher payout because of lower risk, and greater Institutional and insider's ownership lead to lower payout ratio which can be due to the reason that managers have an incentive to reduce dividends in order to increase the expected value of their stock options received as executive compensation. Surprisingly, Debt to equity ratio was found to be positively related with dividend payout, for which they argue that firms are willing to increase debt to finance increasing dividends in order to send a strong positive signal to institutional owners to enhance reputation and maintain access to capital.

Dhanani (2005) adopted survey methodology along with secondary financial and non-financial company data. The data of survey methodology consisted of top 800 firms listed at London Stock Exchange (LSE). The survey opted to examine empirically the importance and relevance of various theories of dividend in UK companies and to measure the extent to which these theories are influenced by corporate characteristics of size and industry sectors. The results indicated that UK managers support the general dividend relevance hypothesis, Companies generally refute the residual dividend policy for investment decisions, and also believe that dividend decisions allow limited flexibility with which to influence capital structure decisions which is in line with signaling hypothesis.

From emerging economy of Pakistan, Ayub (2005) studied the impact of firm specific factors on corporate dividend payments. He analyzed 180 companies listed at KSE during 1981 to 2002 and reported that only 23\% of incremental profits are transformed in to dividend and remaining profits are utilized for additional investments and companies start paying dividend after a certain level of growth. Moreover, large number of shares held by directors lead to high dividend and low reserve funds. He also found liquidity as negatively whereas profitability, insiders' ownership and retained earnings as positively related with payment of cash dividend.

Khan (2006), analyzed the ownership structure of 330 large listed UK firms, her results indicated negative relationship between dividends and ownership concentration. She further analyzed ownership compositions and reported that ownership by insurance companies is positively but individual ownership is negatively related with dividend policy.

Kumar (2006) investigated the relationship between corporate governance and dividend payout for a panel of Indian firms from 1994 to 2000 and explained the difference in dividend behavior with the help of firm's financial structure, investment opportunities, dividend history, earning trends, and the ownership structure. He found positive relationship of dividend with earning trends and investment opportunities and negative relationship with debt-equity ratio and also the ownership by corporations and directors was positively related with dividend decision, but squared corporate ownership was negatively related with dividend but he found no evidence of relationship of foreign ownership and dividend payout.

Naceur et. al. (2006) analyzed dividend policy of 48 firms listed at Tunisian Stock Exchange during 1996 to 2004 and found that Tunisian firms rely both on current earnings and past dividends to fix their dividend payments but the former seems to be more influencing. Using dynamic panel regression they argued that 
profitable firms with more stable earnings can afford large free cash flows and thus pay large dividends and they distribute large dividends when they are growing fast but the liquidity of the stock market and size were negatively related, and ownership concentration and financial leverage had no significant impact on dividend policy.

Pappadopoulos and Dimitrios (2007) investigated the impact of firm's specific characteristics on dividend payout of 72 companies listed at Athens Stock Exchange from 1995 to 2002. They split the sample into retail and industrial firms but found no statistically significant difference in dividend payout of retail and industrial firms and suggested that cash flow is the most important dividend payout determinants and is positively related with dividend payments.

From emerging economy of Jordan Al-Malkawi (2007) examined the determinants of dividend policy using the panel data of publically traded firms on Amman Stock Exchange between 1989 and 2000. Results from Tobit specification suggested that proportion of stock held by insiders and state ownership significantly affect payout while size, age and profitability were found to be the determining factors of dividend policy in Jordan. The results strongly supported the Agency Hypothesis and were broadly consistent with Pecking Order Hypothesis but inconsistent with Signaling Hypothesis.

Recently, Anil and Sujjata (2008) examined the determinants of dividend payout in Indian Information Technology Sector from 2000 to 2006 and found liquidity and Beta (year to year variability in earnings) the only significant determinants of dividend payout.

Jakob and Johannes (2008) in their study on dividend policy in Denmark identified 3948 firm-year observations from 356 firms during 1988-2004 and found that the dividend payers in Denmark are characterized by positive earnings, high ROE, low volatility in ROE, high retained earnings, large size, and payment of dividend in last year but no relationship is found between market to book ratio, leverage ownership structures and dividend decision in Denmark

More recently in Pakistani context, Ahmed and Attiya (2009) analyzed determining factors of dividend policy in emerging economy of Pakistan on a sample of 320 firms listed at KSE from 2001 to 2006. Firstly, they analyzed Lintner, Fama and Babiak Proposed models, which were the extension of partial adjustment model using Panel Regression and found that Pakistani companies rely more on current earnings and past dividend to fix their dividend payment. Secondly, they analyzed the determinants of dividend payout and found that firms with stable positive net earnings pay larger dividends. Furthermore, the ownership concentration and market liquidity are positively related with dividend payout ratio but Growth opportunities had no impact on dividend payment and size of the firms found to be negatively and significantly related with payouts.

The studies of Ayub (2005) and Ahmed and Attiya (2009) have provided the baseline to our study. Ayub (2005) focused on the role of corporate governance related factors in designing dividend policy, whereas, Ahmed and Attiya (2009) investigated the impact of general corporate characters on dividend payouts. However, cash flow which is relatively more important than mere profitability was not considered by both studies. Cash flows are more useful than accruals in predicting dividend changes since cash flows are a more direct liquidity measure (Charitou and Nikos, 1998). Regarding ownership structure, Ayub (2005) argued that increased ownership by managers increases the corporate dividend payouts, however, in Pakistan where majority of companies have concentrated family ownership structures and management practices are not strongly monitored, managerial ownership is expected to have negative relationship with dividend payouts. Therefore, the present study attempts to explore the impact of ownership structure, cash flow sensitivity and operating cash flows on dividend payout behavior of companies in emerging economy of Pakistan.

\section{Data and Methodology}

The data of 100 companies representing all major sectors of KSE has been collected from 2005 to 2007, using the following criteria:

1). Firms were listed at KSE during years 2005 to 2007.

2). Ownership data was available for all years under study.

3). Should not be in loss during the whole study period.

4). Should not have missed dividend payment in more than 1 year from 2005-2007.

5). Should not be a State Owned Enterprise.

OLS regression is among the widely used technique to investigate the impact of firm specific characteristics on dividend behavior (See for example; Ayub, 2005; Kumar, 2006; Al-Malkawi, 2007; Anil and Sujjata, 2008; Ahmed and Attiya, 2009). We have used the same estimation technique to analyze the impact of ownership 
structures and cash flow characters on dividend behavior of companies listed in KSE Pakistan.

\subsection{Variables of the study}

The variables used in the study are summarized in the table 3.1:

[Insert Table 3.1 here]

Dividend payout and dividend intensity are taken as the dependent variables. Since dividend payout is the widely used proxy for dividend policy, almost every financial researcher has used payout as a proxy for corporate dividend policy (See for example Gugler, 2003; Reddy and Rath, 2005; Papadopoulos, 2007; Al-Malkawi, 2007; Ahmed \& Attiya, 2009). In order to calculate dividend payout, total cash dividend per share by the company is divided by earnings after tax per share. For this purpose the reported earning per share is not considered because the denominator, number of outstanding shares, is calculated on the basis of weighted average, so to avoid the measurement bias earning per share is calculated by dividing earning after tax to number of outstanding shares. To check for robustness of results following Kumar (2006) we have used dividend intensity not only to counter the problem due to censoring of dividend payouts but also to check the robustness of results obtained from dividend payout.

In order to analyze Managerial ownership, we have used proportion of shares held by Board of Directors (BOD) and Executive Officers (see, for example, Rozeff, 1982, Jensen et al., 1992, and Holder et al., 1998). It has been argued that agency costs may be reduced if insiders (managers, directors, and other executive officers) increase their ownership in the firm, because this can help to align the interests of both managers and shareholders (Jensen and Meckling, 1976), the higher the proportion of managerial ownership in firm, the less would be the need for using dividends as a tool of reducing agency cost (Al-Malkawi, 2007). Therefore we expect a negative relationship of ownership structure and dividend payments. For individual ownership, proportion of shares held by individual investors is considered (see Khan, 2006), while calculating individual's proportion of shares, manager's proportionate share is excluded where it is reported under the heading 'individual's shareholdings'. Based on Pakistan's taxation policy, capital gain is exempted form tax but dividend is taxed at source, therefore individual investors are expected to prefer capital gain instead of cash dividends, based on which we expect negative relationship of Individual ownership with Dividend Payments.

Operating Cash Flow (OCF) represents the level of cash flow from operating activities; a strong positive relationship of operating cash flow and dividend payments is expected. According to Jensen's (1986) Free Cash Flow Hypothesis, companies prefer to use their cash resources to invest in profitable projects first; dividend is paid out of residual. From a company's point of view, cash generated from operations plays an important role in deciding the level of payout, among all three sources of cash flows i.e. operating; investing and financing, cash generated from operations is considered as most desirable source of funds for the company for distribution of dividends. Anil and Sujjata (2008) also found cash flow from operations as the most significant determinant of dividend policy in Indian IT industry, they considered log to the base "e" of operating cash flow as a proxy of liquidity. Based on existing literature we expect a positive relationship between operating cash flow and proxies of dividend behavior. For measuring a firm's level of firms' Cash Flow Sensitivity (CFS), following Khurana et. al. (2006) we used annual change in cash holdings to total assets as a proxy. Based on the intuition that financially constrained firms try to accumulate cash to invest in future profitable projects, cash flow sensitivity is expected to have negative relationship with a firm's potential to pay dividend.

We have used three control variables, size, leverage and profitability in this study. Existing literature suggests that size may be inversely related to the probability of bankruptcy (Ferri and Jones 1979; Titman and Wessels 1988; Rajan and Zingales 1995). In particular, larger firms should have easier access to external capital markets and can borrow on better terms, because of limited resources the conflicts between creditors and shareholders are more severe for smaller than larger firms. Moreover, large firms tend to be more diversified and their cash flows are more regular and less volatile. Therefore, large firms should be more willing to pay out higher dividends. To measure firm size Log of Assets is considered and is expected to have positive relationship with dividend behavior. Secondly, Leverage is considered as a control variable, besides the fact that debt has the tendency to leaver up shareholders return but it also entails risk, that is, when a firm acquires debts, it commits itself to a fixed financial charge, interest, and repayment of principal, failure to which can lead a firm into liquidation. To avoid liquidation a firm, therefore, must maintain good liquidity position and cash flows which ultimately effects dividend payout negatively (Gugler and Yurtoglu, 2003; Aivazian et al., 2004). Total liabilities to total assets are considered a measure of a firm's financial leverage and expected to have negative relationship with payout. Finally, profitability represents firm's primary source of fund generation, firms suffering from losses are unlikely to pay dividends due to deficiency of funds or risk of bankruptcy. Therefore a firm's profitability is expected to have a positive relationship with dividend payouts. A firm's earning per share (EPS) is considered as a proxy of 
its profitability.

\subsection{Models}

In order to analyze the impact of firm specific factors on dividend behavior of companies three models have been designed, each consists of two regression equations. Model 1 analyzes the impact of ownership structure using two proxy variables in which MNG represents the proportion of Managerial Ownership and IND represents the proportion of individual ownership (excluding management's proportion). Furthermore, control variables of size, leverage and profitability are also included in the model. For robustness of results we have used dividend intensity as dependent variable. The regression equations 3.1 and 3.2 have been used to estimate the impact of ownership structure on dividend behavior.

$$
\begin{aligned}
& (D P O)_{i t}=\alpha_{0}+\beta_{1}(M N G)_{i t}+\beta_{2}(I N D)_{i t}+\beta_{3}(S Z)_{i t}+\beta_{4}(L V R G)_{i t}+\beta_{5}(P R F T)_{i t}+\varepsilon_{i t} \\
& (D I V I N T)_{i t}=\alpha_{0}+\beta_{1}(M N G)_{i t}+\beta_{2}(I N D)_{i t}+\beta_{3}(S Z)_{i t}+\beta_{4}(L V R G)_{i t}+\beta_{5}(P R F T)_{i t}+\varepsilon_{i t}
\end{aligned}
$$

Model 2 investigates the impact of cash flow characteristics using two variables in which OCF represents the operating cash flow of the company and CFS represents cash flow sensitivity along with three control variables i.e. size, leverage and profitability whereas dividend intensity is used for robustness check. The regression equations 3.3 and 3.4 estimate the impact of cash flow characteristics on dividend payouts and dividend intensity respectively.

$$
\begin{aligned}
& (D P O)_{i t}=\alpha_{0}+\beta_{1}(O C F)_{i t}+\beta_{2}(C F S)_{i t}+\beta_{3}(S Z)_{i t}+\beta_{4}(L V R G)_{i t}+\beta_{5}(P R F T)_{i t}+\varepsilon_{i t} \\
& (D I V I N T)_{i t}=\alpha_{0}+\beta_{1}(O C F)_{i t}+\beta_{2}(C F S)_{i t}+\beta_{3}(S Z)_{i t}+\beta_{4}(L V R G)_{i t}+\beta_{5}(P R F T)_{i t}+\varepsilon_{i t}
\end{aligned}
$$

Model 3 is a joint model which analyzes the combined effect of ownership structure and cash flow characteristics on dividend behavior. The regression equations 3.5 and 3.6 estimates the combined impact of all variables previously used on proxies of dividend behavior.

$$
\begin{aligned}
& (D P O)_{i t}=\alpha_{0}+\beta_{1}(M N G)_{i t}+\beta_{2}(I N D)_{i t}+\beta_{3}(\text { OCF })_{i t}+\beta_{4}(C F S)_{i t}+\beta_{5}(S Z)_{i t}+\beta_{6}(L V R G)_{i t}+\beta_{7}(P R F T)_{i t}+\varepsilon_{i t} \\
& (D I V I N T)_{i t}=\alpha_{0}+\beta_{1}(M N G)_{i t}+\beta_{2}(I N D)_{i t}+\beta_{3}(O C F)_{i t}+\beta_{4}(C F S)_{i t}+\beta_{5}(S Z)_{i t}+\beta_{6}(L V R G)_{i t}+\beta_{7}(P R F T)_{i t}+\varepsilon_{i t}
\end{aligned}
$$

(All variables have been explained in table 3.1)

\section{Results Discussion}

Given below are the results of regression equations on a sample of 256 firm-year observations (Note 1)

[Insert Table 4.1 here]

The results of Table 4.1 reveal that managerial ownership has significant and negative relationship with dividend payout and dividend Intensity in Model 1 which is in agreement with Meyers and Frank (2004). In Pakistan management practices are not strongly monitored by corporate law authorities, that is why corporate managers seem to have greater tendency to increase funds under their control at the expense of low dividend payouts. Jensen (1986) also provided evidence that the managers, who are reluctant to pay dividend, are reluctant to give up control over earnings" (cited in Belden et. al., 2005). Individual's ownership coefficient is also significantly negative which shows that individual investors do not prefer dividends over capital gain, which could be due to double taxation on dividend and no tax on capital gain, supporting tax preference hypothesis. In addition, majority of individual investors seems to be interested in speculative profit rather than long term investments in equity shares and the dividend is not considered as an instant source of funds which reduces individual's inclination towards dividend. As a result companies also seem reluctant to pay a high dividend, which is inline with the "Catering Theory". According to which, management gives incentives to shareholders as per their expectations and pay dividend only when investors put premium on shares of dividend paying companies. The reducing importance of dividends adversely affects the corporate payouts and is partly the reason of disappearing dividends form Pakistani Stock Market. Similar results have been observed by Wei (2003) and Khan (2006) who reported negative relationship between individual ownership and dividends in Chinese and UK firms respectively. Overall explanatory power of the model is $14 \%$ with dividend payout and $23.70 \%$ with dividend intensity.

Model 2 captures the impact of cash flow from operations and cash flow sensitivity on dividend payout and dividend intensity. The results show significant positive relationship between operating cash flow with both proxies of dividend behavior. This relationship shows that operating cash flows are of significant importance in determining the level of cash dividends in Pakistan. It also shows that cash flow sensitivity is insignificant but negatively related with dividend payout and has a significantly negative relationship with dividend intensity. Similar results were reported by Alemeida et. al., (2004) who argued that firms facing financial constraints in future respond to those potential constraints by accumulating cash today which makes firm more cash sensitive, this accumulation of cash negatively affect cash dividends of companies. Intuitively, firms which are sensitive to 
cash flow would be reluctant to pay high dividends. Operating cash flow and cash flow sensitivity along with control variables of size, leverage and profitability explain $8 \%$ and $35.5 \%$ of total variation in dividend payout and dividend intensity respectively.

Finally, Model 3 analyses the combined impact of all variables on dividend behavior. The results of joint model (Model 3) show managerial ownership, individual ownership and operating cash flow as the most significant determinants of dividend behavior. The coefficient of cash flow sensitivity is insignificant with dividend payout but significantly and negatively related with dividend intensity. The overall explanatory power of Model 3 is $15 \%$ for dividend payout and $40.6 \%$ for dividend intensity.

All models include three control variables in which size is used as first control variable having significantly negative relationship with dividend behavior. Existing literature shows mixed results on the relationship of size and dividend payouts where majority of researchers have reported the positive relationship of size with dividend payouts (See for example, Stacescu, 2006; Al-Malkawi, 2007) while others have reported negative relationship (See for example, Naceur, 2006; Avazian et. al., 2006; Ahmed and Attiya, 2009). In the context of Pakistan, Ahmed and Attiya (2009) have found similar results and reported negative relationship of firms' size with dividend payouts which can be due to large firms' preference to retain dividends in order to avoid costly financing. Another explanation of negative co-efficient of size could be the period of study i.e. 2005 to 2007, which is considered as the period of economic boom in which GDP growth rate reached up to $6.9 \%$ (in 2007) and was recorded as the highest in Asia (Economic Survey of Pakistan, 2007-08). But this rate declined again to $5.8 \%$ in 2008 and Pakistan's economy was hit by the worst crises of its history driven by energy shortage, disappointing harvest in key cash crops and policy uncertainty during the transition of the government. It seems that large size firms might be expecting this dramatic deterioration, therefore, they started building up their reserves instead of dividend payments while small firms, being myopic, tried to attract investors through high dividend as they don't have easy access to external capital markets.

Leverage is negatively but insignificantly related with dividend payout showing lesser importance of Debt Ratio in determining dividend payout which is inline with the results reported by Baker et. al. (2007) and Ahemd and Attiya (2009) but contradicts the results of Mayers and Frank (2004) who reported positive relationship of leverage and dividend payouts. The insignificant relationship of leverage seems to be in line with Ayub (2005) who argued that the public debt market is not well established in Pakistan and majority of loan are sanctioned on socio-political basis and such loans are sanctioned only for a particular project and are not contributed in capital employed by the company. Therefore, debt cannot be considered as having a direct bearing on the corporate dividend policy in Pakistan.

Profitability is also positively but insignificantly related with dividend payout but significantly related with dividend Intensity which is inline with the results of Mayers and Frank (2004) in general and Avazian et. al. (2003) specifically in Pakistani context, who reported insignificant positive relationship of profitability with dividend payouts.

\section{Conclusion and Policy Implications}

Although, timely payment of dividend has a positive impact on reputation of company in equity market, but unfortunately, corporate dividend payouts in Pakistan are very low as compared to other emerging economies. During last three years, the number of dividend paying companies has been reduced to $40 \%$ in 2007 as compared to $46 \%$ in 2005 (Annual Report KSE, 2008). The objective of the current study is to investigate the reasons behind declining dividends, in general, and to explore the impact of ownership structure and cash flows on corporate dividend payouts, in particular. In context of Pakistan, recently Ayub (2005) and Ahmed and Attiya (2009) have studied determinants of dividend policy but both studies did not consider the cash flow aspect, which is argued by many researchers as a potential determinant of dividend policy (See for example, Lawson, 1996; DeAngelo and DeAngelo, 2006; ). Furthermore, the evidence on impact of ownership structures on payout of Pakistani companies is also very limited. Therefore, present study attempts to extend this literature by examining the impact of cash flows and ownership structure on corporate payouts. The data of 100 companies representing all major sectors of KSE has been collected from 2005 to 2007 and analyzed using OLS regression. The estimated results show that the companies in which high proportion of shares are held by managers and individual are more reluctant of pay high dividends as compared with the companies in which managerial and individual ownership is low. However, high operating cash flows increase companies' potential to pay high dividends. Although, cash flow sensitivity reduces the companies' payouts but still it is not among the potential determinants of corporate payouts in Pakistan. Large and highly leveraged firms are more reluctant to pay high dividend as compared to small and low leveraged firms, while profitability increases the companies' dividend 
payouts.

The above findings reveal the fact that corporate managers try to accumulate funds under their control at the expense of low payouts because managerial practices are not strictly monitored and investors' rights are not strongly protected in Pakistan, which seems to be the main reason of disappearing dividends form Pakistani stock market. Furthermore, individual investors consisting of stock brokers, agents, dealers, retired civil servants, businessmen, professionals and small jobholders, are more interested in capital gain from short selling and long buying based rather than dividends. A possible reason for the preference of capital gain over dividends could be the exemption of capital gain from tax as compared with dividends which are subject to double taxation. Although operating cash flow is the most desirable source of cash dividends but our data shows that during last seven years the corporate operating cash flow to total assets ratio has declined from 0.167 to 0.117 which has also contributed towards declining corporate dividends. Surprisingly, large companies have been found more reluctant to pay high dividends which might be because large companies try to save more cash for reinvesting in assets, whereas, small companies, having little access to external debt market try to improve the demand of their shares by paying dividends to accumulate required sum of money from issuance of equity shares at better price.

Based on the results, it is suggested that corporate law authorities should discourage concentrated family ownerships in companies and due protection should be given to minority shareholders against expropriation of minority rights. This could be done by formulating policy and procedures through which minority shareholders can approach SECP in case they any mismanagement in company's affairs. SECP should also discourage increasing speculative activities in the stock markets by reducing withholding tax on dividend income to encourage long term investment in shares. Furthermore, in order to encourage companies to pay dividends, corporate tax authorities should announce tax incentives to such companies who pay regular dividends. Corporate managers, on the other side, should focus on increasing companies' operating cash flows in order to make their companies able to pay high and regular dividends which will ultimately raise the market price of their equity shares.

The scope of this study is limited to 3 years data of 100 companies listed at KSE Pakistan, and therefore, represents the nature and trends of dividend payouts of listed companies during the window period from 2005 to 2007 only. Results from this study can be refined further by increasing the sample size and study period. Furthermore, due to non-availability of ownership data of most of the companies, only managerial and individual ownerships have been studied, future researchers may study the impact of Institutional ownership on dividend payouts. The sample may further be classified in to financial and non-financial companies, regular dividend paying and irregular dividend paying companies.

\section{References}

Afza, Talat and Ch. Slahudin. (2009). Management Ownership and Firm Performance: Evidence from An Emerging Economy, Corporate Ownership and Control Journal, Vol.6, issue 4, pp.88-95.

Ahmed, H. and J. Attiya. (2009). Dynamics and Determinants of Dividend Policy in Pakistan (Evidence from Karachi Stock Exchange Non Financial Firms), International Journal of Finance and Economics, Issue 25, 148-171.

Aivazian, Varouj, L. Booth, and S. Cleary. (2004). Dividend Smoothing, Working Paper, (University of Toronto, Rotman).

Aivazian, Varouj, L. Booth, and S. Cleary (2003). Do Emerging Market Firms Follow Different Dividend Policies from U.S. Firms, The Journal of Financial Research, XXLI, 371-387.

Al-Malkawi, H. A. N. (2007). Determinants of Dividend Policy in Jordan, An application of Tobit Model. Journal of Economic and Administrative Sciences, Vol. 23, No. 2, 44-70.

Anil, K. and K. Sujata. (2008). Determinants of dividend payout ratio-A study of Indian Information Technology Sector, International Research Journal of Finance and Economics, Issue 15(2008), 63-71.

Ayub, M. (2005). Corporate Governance and Dividend Policy, Pakistan Economic and Social Review 1 XLIII (2005): pp. 115-128.

Baker, M. and J. Wurgler. (2004). A catering theory of dividends, Journal of Finance 59 (3), 1125-1165.

Baker. K. H. Saadi.S, D. Gandhi.D. (2007). 'the perception of dividend by Canadian managers: new sury evidence', International Journal of Managerial Finance, vol.3, 2007

Belden, S., F. Todd and K. Bob. (2005). Dividends and Directors: Do Outsiders Reduce Agency Costs?, Business and Society Review 110:2,171-180. 
Berle, A. and G. Means. (1932). The Modern Corporation and Private Property, Macmillan Publishing, New York.

Bhattacharya, S. (1979). Imperfect information, dividend policy and the bird in the hand fallacy, Bell Journal of Economics 10, 259-27.

Black, F. (1976). The Dividend Puzzle, Journal of Portfolio Management 2, 5-8.

Bradley, Michael, Dennis R. Capozza, and P. J. Seguin (1998). Dividend Policy and Cash-Flow Uncertainty, Real Estate Economics 26, 555-580.

Darling, P.G. (1957). The Influence of Expectations and Liquidity on Dividend Policy, Journal of Political Economy, 65(3), p 209-224.

DeAngelo, H. \& DeAngelo, L. (2006). The irrelevance of the MM dividend irrelevance theorem. Journal of Financial Economics 79, 293-316.

DeAngelo, Harry, L. DeAngelo. and D. J. Skinner (1992). Dividends and Losses, Journal of Finance 47, 1837-1863.

Dhanani A. (2005). The Corporate Dividend Policy; The Views of British Financial Managers, Journal of Business Finance and Accounting, September/October, 2005, 0306-686X, 32(7) \& (8), p 1625-1672.

Easterbrook and H. Frank. (1984). Two Agency- Cost Explanations of Dividends," American Economic Re view, Vol. 74, September 1984, 650- 659.

Fama, E. and H. Babiak. (1968). Dividend policy of individual firms: an empirical analysis, Journal of the American Statistical Association, 63, 1132-1161.

Fama, Eugene F. and K. R. French. (2002). Testing Trade-Off and Pecking Order Predictions about Dividends and Debt, The Review of Financial Studies 15, 1-33.

Ferri, M. G. and W. H. Jones. (1979). 'Determinants of Financial Structure: A New Approach', Journal of Finance, 34, 631-44.

Ferris, S. P., N. Sen and H. P. Yui. (2006). God Save the Queen and Her Dividend, Corporate Payouts in United Kingdom, Journal of Business, Vol 79, No. 3, 1149-1173.

Frankfurter, George M. and Bob G. Wood, Jr. (2002). Dividend Policy Theories and Their Empirical Tests, International Review of Financial Analysis 11, 111-138.

Gordon, M. J, (1963). 'Optimal investment and financing policy', Journal of Finance, Vol. 18 No. 2, 264-72.

Gugler, K. (2003). Corporate Governance, Dividend Payout Policy, and the interrelationship between dividend, R\&D and Capital Investment, Journal of Banking and Finance (27), pp.1197-1321.

Ho, H. (2002). Dividend policies in Australia and Japan, International Advances in Economics, Res 9(2), p 91-100.

Holder, Mark E., F. W. Langrehr and J. L. Hexter. (1998). Dividend Policy Determinants: An Investigation of the Influences of Stakeholder Theory, Financial Management 27, 73-82.

Ibrahim, A. A. (2005). Corporate Governance in Pakistan: Analysis of Current Challenges and Recommendations for Future Reforms, Securities and Exchange Commission of Pakistan's Second Annual Conference on Corporate Governance, June 3-4.

Jakob S. H.and Johannes R. (2008). Dividend Determinants in Denmark, Management Working Paper 2008-3, University of Aarhus, Denmark.

Jensen and C. Michael. (1986). Agency Costs of Free Cash Flow, Corporate Finance, and Takeovers, The American Economic Review, 76, 323-329.

Jensen, C. Micheal and W. H. Meckling. (1976). Theory of Firm: Managerial Behavior, agency cost and Capital structure, Journal of Financial Economics 3, 305-360.

Jensen, G. R., D. P. Solberg, and T. S. Zorn. (1992). Simultaneous Determination of Insider Ownership, Debt, and Dividend Policies, Journal of Financial and Quantitative Analysis 27, 274-263.

Jensen, M. (1993). "The Modern Industrial Revolution Exit, and the Failure of Internal Control Systems," Journal of Finance, 48 (3): 831-880.

Khan, T. (2006). Companies dividend and ownership structure: Evidence from UK panel data, The Economic 


\section{Journal 116, C172-C189.}

Khurana, I. K., X. Martin and R. Pereira. (2006). Financial Development and Cash Flow Sensitivity of Cash, Journal of Financial and Quantitative Analysis, Vol 41, No. 4, December 2006, 787-807

Kumar, J. (2006). Corporate Governance and Dividend Policy in India, Journal of Emerging Market Finance, Vol. 5, No. 5, pp. 15-58.

Lawson, G. (1996). 'The Measurement of the Economic Performance of the US Nonfinancial Corporate Business Sector 1946^1990: An Application of the Shareholder Value Creation Concept', European Accounting Review, Vol. 5, No. 4, pp. $715^{\wedge} 41$.

Lintner, J. (1956). "Distribution of Incomes of Corporations among Dividends, Retained Earnings and Taxes,"/Imencan Economic Review (May 1956), pp. 97-113.

Miller, M.H. and F. Modigliani. (1961). "Dividend Policy, Growth, and the Valuation of Shares," Journal of Business (October), 411-433.

Myers, M. and B. Frank. (2004). The Determinants of Corporate Dividend Policy, Academy of Accounting and Financial Studies Journal, Vol. 8, No. 3, 17-28.

Myers, Stewart C. (1984). "The Capital Structure Puzzle", Journal of Finance 39, 575-592.

Naceur, S. B., M. Goaied and A. Belanes. (2006). On the Determinants and Dynamics of Dividend Policy, International Review of Finance, 6:1-2, PP: 1-23.

Nishat, M. and M. Irfan. (2003). Dividend Policy and Stock Price Volatility in Pakistan, 11th Pacific Basin Finance, Economics and Accounting Conference.

Papadopoulos, D. L. and P. C. Dbmitrios. (2007). Focus on present status and Determinants of Dividend Payout Policy: Athens Stock Exchange in Perspective, Journal of Financial Management and Analysis, 20 (2), 24-37.

Purnanandam, J. and K. S. Hanumanta. (1965). Corporate Dividend and Target Payout Ratio in India: 1946-1963, Indian Journal of Commerce, pp: 38-43.

Rajan, Raghuram G., and L. Zingales. (1995). What Do We Know About Capital Structure? Some Evidence from International Data, Journal of Finance 50, 1421-1460.

Ramcharran, Harri. (2001). An Empirical Model of Dividend Policy in Emerging Equity Markets, Emerging Markets Quarterly 5, 39-49.

Reddy, Y. and S. Rath. (2005). Disappearing Dividends in Emerging Markets, Emerging Market Finance and Trade, Vol. 41, No. 6, pp.58-82.

Rozeff and Michael S. (1982). Growth, Beta and Agency Costs as Determinants of Dividend payout Ratios, The Journal of Financial Research 5, 249-259.

Stacescu, B. (2006). Dividend Policy in Switzerland, Financial Markets Portfolio Manangement, 20:153-183.

Titman, S. and R. Wessels. (1988). 'The Determinants of Capital Structure', Journal of Finance, 43, 1-19.

Wie, Gang, W. Zhang and J. Z. Xiao. (2003). Dividend Policy and Ownership Structure in China, SRNN Working Paper Series No. 463924, [online], (www.ssrn.com).

\section{Notes}

Note 1. For refinement in results another sample with more strict criteria has been analyzed in which only those companies have been included in the sample that paid dividend in all three years (i.e. 2005-2007) which has reduced our sample size to 180 firm-year observations but increased the explanatory power (Adjusted R-Square) of all regression models. The results of regression equations from new sample have shown slight increase in coefficient values but no change has been observed in signs of coefficients and level of significance in any of the models.

\section{Acknowledgement}

This research paper has been presented in " 3 rd International Colloquium on Business and Management (ICBM) Bangkok 2010", Thailand, held from 25-28 January, 2010 and is also a part of MS Thesis of Hammad Hassan Mirza, titled "Determinants of Corporate Dividend Policy in Emerging Economy of Pakistan". 
Table 3.1 Variables of the study

\begin{tabular}{|l|l|l|l|}
\hline \multicolumn{1}{|c|}{ Symbol } & \multicolumn{1}{|c|}{ Variable description } & \multicolumn{1}{c|}{ Proxy } & \multicolumn{1}{c|}{$\begin{array}{c}\text { Expected } \\
\text { relationship }\end{array}$} \\
\hline Dependent Variable & Dividend paid per share / Net Earning per share & Dividend Behavior & \\
\hline DPO & Total Dividend Paid/ Total Assets & Dividend Behavior & \\
\hline DIVINT & & \\
\hline Independent Variables & Proportion of shares held by Directors and Executives & Managerial Ownership & Negative (-) \\
\hline MNG & Proportion of shares held by Individuals & Individual Ownership & Negative (-) \\
\hline IND & Operating Cash Flow / Total Assets & Operating Cash & Positive $(+)$ \\
\hline OCF & $\Delta$ Cash Balance / Total Assets & Cash Flow Sensitivity & Negative $(-)$ \\
\hline CFS & Log of Assets & Size & Positive $(+)$ \\
\hline SZ & Total Liabilities / Total Assets & Capital Structure & Negative $(-)$ \\
\hline LVRG & Earning Per Share & Profitability & Positive $(+)$ \\
\hline PROFT & &
\end{tabular}

Table 4.1.

\begin{tabular}{|c|c|c|c|c|c|c|}
\hline \multirow[b]{2}{*}{ VARIABLES } & \multicolumn{2}{|c|}{ MODEL 1} & \multicolumn{2}{|c|}{ MODEL 2} & \multicolumn{2}{|c|}{ MODEL 3} \\
\hline & $\begin{array}{c}\text { DPO } \\
\text { (EQ 3.1) }\end{array}$ & $\begin{array}{l}\text { DIVINT } \\
\text { (EQ 3.2) }\end{array}$ & $\begin{array}{c}\text { DPO } \\
\text { (EQ 3.3) }\end{array}$ & $\begin{array}{l}\text { DIVINT } \\
\text { (EQ 3.4) }\end{array}$ & $\begin{array}{c}\text { DPO } \\
(\text { EQ 3.5) }\end{array}$ & $\begin{array}{l}\text { DIVINT } \\
\text { (EQ 3.6) }\end{array}$ \\
\hline CONSTANT & $\begin{array}{l}1.794 * * * \\
(4.727)\end{array}$ & $\begin{array}{l}\mathbf{0 . 2 7 2} * * * \\
(4.144)\end{array}$ & $\begin{array}{l}\mathbf{0 . 9 6 1 * * *} \\
(2.807)\end{array}$ & $\begin{array}{l}\mathbf{0 . 0 4 7} \\
(0.915)\end{array}$ & $\begin{array}{l}\text { 1.573*** } \\
(3.980)\end{array}$ & $\begin{array}{l}\mathbf{0 . 1 7 8}^{* * * *} \\
(2.909)\end{array}$ \\
\hline MNG & $\begin{array}{l}\mathbf{- 0 . 4 0 5} * * * \\
(-4.406)\end{array}$ & $\begin{array}{l}\mathbf{- 0 . 0 6 9} * * * \\
(-4.303)\end{array}$ & -- & -- & $\begin{array}{l}-\mathbf{0 . 3 5 9} * * * \\
(-3.800)\end{array}$ & $\begin{array}{l}\mathbf{- 0 . 0 4 7 * * *} \\
(-3.188)\end{array}$ \\
\hline IND & $\begin{array}{l}\mathbf{- 0 . 4 0 1 * * *} \\
(-3.270)\end{array}$ & $\begin{array}{l}\mathbf{- 0 . 1 0 1} * * * \\
(-4.743)\end{array}$ & --- & --- & $\begin{array}{l}\mathbf{- 0 . 3 3 1 * *} \\
(-2.548)\end{array}$ & $\begin{array}{l}\mathbf{- 0 . 0 6 9} * * * \\
(-3.432)\end{array}$ \\
\hline OCF & -- & -- & $\begin{array}{l}\mathbf{0 . 6 7 4 * * *} \\
(3.040)\end{array}$ & $\begin{array}{l}\mathbf{0 . 2 4 2} * * * \\
(7.312)\end{array}$ & $\begin{array}{l}\mathbf{0 . 4 5 9} * * \\
(2.017)\end{array}$ & $\begin{array}{l}\mathbf{0 . 2 1 6 * * *} \\
(6.163)\end{array}$ \\
\hline CFS & -- & -- & $\begin{array}{l}\mathbf{- 0 . 3 8 9} \\
(-0.997)\end{array}$ & $\begin{array}{l}\mathbf{- 0 . 1 7 0 * * *} \\
(-2.921)\end{array}$ & $\begin{array}{l}\mathbf{- 0 . 4 2 9} \\
(-1.061)\end{array}$ & $\begin{array}{l}\mathbf{- 0 . 2 0 3} * * * \\
(-3.248)\end{array}$ \\
\hline SZ & $\begin{array}{l}-\mathbf{0 . 0 5 6} \% * * \\
(-3.312)\end{array}$ & $\begin{array}{l}-\mathbf{0 . 0 0 8} * * * \\
(-2.903)\end{array}$ & $\begin{array}{l}\mathbf{- 0 . 0 2 8 *} \\
(-1.814)\end{array}$ & $\begin{array}{l}-\mathbf{0 . 0 0 1} \\
(-0.442)\end{array}$ & $\begin{array}{l}\mathbf{- 0 . 0 4 9} * * * \\
(-2.859)\end{array}$ & $\begin{array}{l}\mathbf{- 0 . 0 0 6 * *} \\
(-2.194)\end{array}$ \\
\hline LVG & $\begin{array}{l}\mathbf{- 0 . 1 3 5} \\
(-1.350)\end{array}$ & $\begin{array}{l}\mathbf{- 0 . 0 3 0 *} \\
(-1.762)\end{array}$ & $\begin{array}{l}\mathbf{- 0 . 1 6 1} \\
(-1.619)\end{array}$ & $\begin{array}{l}-\mathbf{0 . 0 3 3} * * \\
(-2.223)\end{array}$ & $\begin{array}{l}\mathbf{- 0 . 1 1 9} \\
(-1.176)\end{array}$ & $\begin{array}{l}\mathbf{- 0 . 0 2 1} \\
(-1.371)\end{array}$ \\
\hline PRFT & $\begin{array}{l}\mathbf{0 . 0 0 0} \\
(0.051)\end{array}$ & $\begin{array}{l}\mathbf{0 . 0 0 0 * * *} \\
(3.289)\end{array}$ & $\begin{array}{l}\mathbf{0 . 0 0 1} \\
(1.581)\end{array}$ & $\begin{array}{l}\mathbf{0 . 0 0 1} * * * \\
(6.342)\end{array}$ & $\begin{array}{l}\mathbf{0 . 0 0 1} \\
(0.922)\end{array}$ & $\begin{array}{l}\mathbf{0 . 0 0 1} \% * * \\
(5.442)\end{array}$ \\
\hline $\mathbf{N}$ & 212 & 212 & 230 & 230 & 208 & 208 \\
\hline R2\% & 16.00 & 25.50 & 10.00 & 36.90 & 18.00 & 42.60 \\
\hline ADJ-R2\% & 14.00 & 23.70 & 08.00 & 35.50 & 15.20 & 40.60 \\
\hline $\mathbf{D} / \mathbf{W}$ & 1.530 & 1.043 & 1.607 & 1.311 & 1.622 & 1.369 \\
\hline
\end{tabular}

Parenthesis contain (t-Statistics); ** significant at level of $1 \%$; ** significant at level of $5 \%$; Significant at level of $10 \%$ 